\title{
Review: The Revelations of a Living Legend: The Memoirs of Dr. Errington Washington Isaac Watkins Sr.
}

\section{Berthamae L. Walker \\ The College of The Bahamas ${ }^{1}$}

\section{ABSTRACT}

Review of The Revelations of a Living Legend: The Memoirs of Dr. Errington Washington Isaac Watkins Sr. Nassau, Bahamas: E. W. I. Watkins, 2011. ISBN: 978-976-95420-06

Biographies and autobiographies add to our understanding of Bahamian history, politics and culture. They also provide a glimpse into the roles that individuals played in shaping The Bahamas as it emerged as an independent nation.

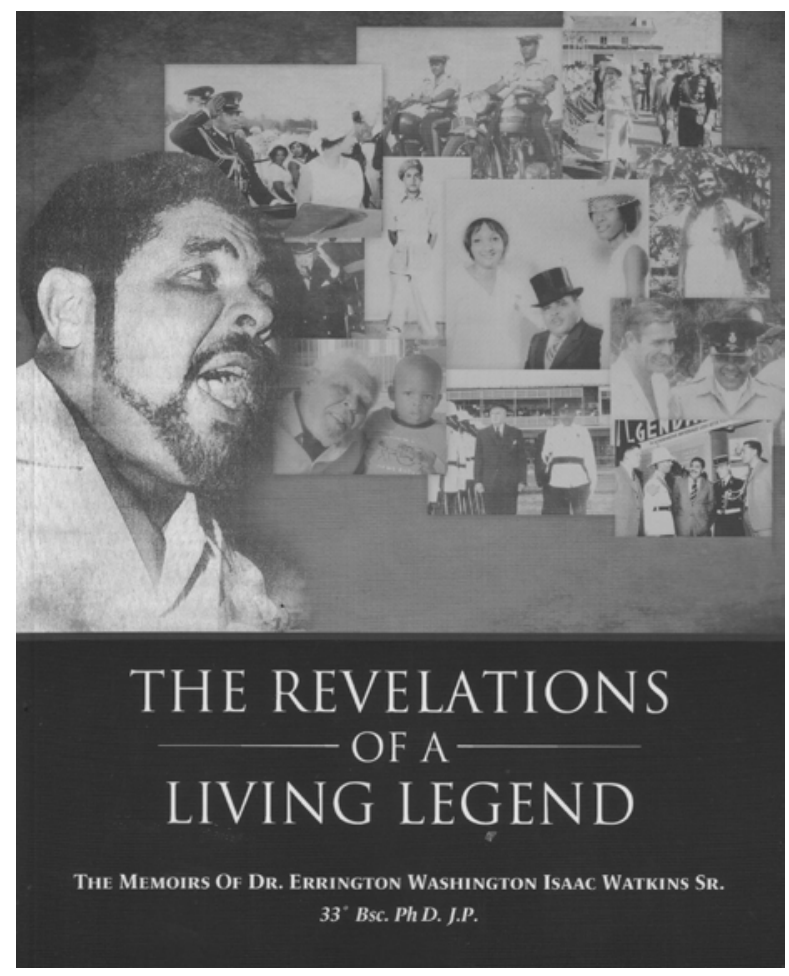

Dr. Errington "Bumpy" Watkins, a former police officer and politician, has published his memoirs, chronicling his life, from his early childhood days in Lower Deadman's Cay, Long Island, the place of his birth, to the capital city of Nassau, the United States, the Caribbean, Europe and back again. This 199page book is indeed a page-turner, filled with passion, humour and history.

The book is organized into three distinct parts. Part 1 focuses on the early childhood of the author; it shows the family dynamics at work for a child born in 1927 growing up in a mixed-race household as a member of a large family. Life in the "Out Islands" (now known as the Family Islands) comes to life as the reader is transported through the author's experience of schooling, family interactions and economic responsibilities. This section also describes the author's career in the Royal Bahamas Police Force and his assignments involving visiting world leaders such as Winston Churchill and Queen Elizabeth II, and celebrities such as Sean Connery.

Part 2 focuses on the author's illustrious

\footnotetext{
${ }^{1}$ B. L. Walker, College Librarian, The College of The Bahamas, P.O. Box N-4912, Nassau, Bahamas. E-mail: berthamae.walker@cob.edu.bs

APA reference: Walker, B. L. (2015). The Revelations of a Living Legend: The Memoirs of Dr. Errington Washington Isaac Watkins Sr. [book review]. The International Journal of Bahamian Studies, 21(1), 116-117. http://dx.doi.org/10.15362/ijbs.v21i1.255
} 
political career. It provides insight into the organizational machinery of the United Bahamian Party (UBP), the Free National Movement (FNM) and the Progressive Liberal Party (PLP). It also chronicles his stint as an independent Member of Parliament. The author paints a vivid picture of the 1962 general elections, Majority Rule events and the individuals who made it possible. This sections ends with his retirement from the Force.

Part 3, the shortest section of the book, details the author's involvement with the agricultural sector in The Bahamas and with civil and charitable organizations.

Overall, this book is filled with life lessons and lessons in Bahamian history and culture. Some of the chapters tend to be very short and could have been combined, but this arrangement does not take away from the content. An index to the book would have been useful especially given the many names mentioned in the text, especially for those interested in tracing their family, the history of law enforcement and political personalities.

The numerous black-and-white photographs strategically placed throughout the text add validity to the content. Included are headlines from The Tribune and The Guardian newspapers of 1973 and The Torch of 1971. Readers will come to know what a "chesterfield" is, and what it feels like to be locked in a morgue overnight - in the 1950's with no refrigeration.

This book is a must-read on matters relevant to Bahamian island and family life, party politics and the development of the Royal Bahamas Police Force. Through historic photos and text, the book gives readers a glimpse into the life of Errington Washington Isaacs Sr., a man who, in the words of the late Cecil Wallace Whitfield, "called the shots as he saw them" and one who "is still driving race cars, riding motorcycles and chasing pretty women” (Watkins, 2011, p. 188). 